\title{
Multiphase flow assurance in subsea pipeline from Ca Ngu Vang oilfield to central processing platform 3 of Bach Ho oilfield
}

\author{
- Pham Son Tung
}

University of Technology, VNU-HCM

- Mai Cao Lan

University of Technology, VNU-HCM

Adjunct Senior Lecturer, University of Southern Queensland, Australia

(Manuscript Received on August 18 ${ }^{\text {th }}, 2014$; Manuscript Revised November 11 $1^{\text {th }}, 2014$ )

\begin{abstract}
The aim of this paper is to find optimal solutions for flow assurance of oil and gas mixture in an undersea pipeline. This study is applied to $25 \mathrm{~km}$ pipeline from the Ca Ngu Vang oilfield to the central processing platform number 3 of the Bach Ho oilfield. From the conservation equations of mass, momentum and energy, together with the theoretical basis of the flow regime, fluid properties, as well as pipeline geometry and properties, two simulations with different flow rates
\end{abstract}

Keywords: Flow assurance, Slug tracking, Slug catcher, Multiphase flow simulation.

\section{INTRODUCTION}

Exploration activities in recent years showed that many oilfields in Vietnam have small reserves of about 50-100 million barrels. Development of such small oilfields presents numerous difficulties due to high risks, high investment and operating costs over a unit of recovery. Research of practical solutions for the development of small oilfields in Vietnam is therefore important and urgent in current period.

One of the best solutions to reduce the cost is to develop connectivity between oilfields: after being extracted from small oilfields, gas and oil are not immediately processed but directly transported to a central processing platform. The optimization of the multiphase transport in this study derived from practical needs for $25 \mathrm{~km}$ undersea pipeline connecting $\mathrm{Ca} \mathrm{Ngu}$ Vang (CNV) oilfield to Central Processing Platform 3 (CPP3) of Bach Ho oilfield (Figure 1). With such a long pipeline, the flow is accompanied by high potential risk, were developed: 1) Slug tracking simulation to predict the formation of slugs: frequency, length and surge volumes. The simulation results helped to find optimal solutions for the reception capability of the slug catcher; 2) Thermal hydraulic simulation to predict the evolution of temperature and pressure in the pipeline in order to help choosing the suitable pour point depressant (PPD) chemicals.

for instance the paraffin and hydrate deposit, the formation of slugs, or changes in temperature, pressure and flow rates during the operation of the pipeline. For consequence, the pipeline will be clogged; the flow is perturbed, which reduces the transport capacity of the system. We all know that a pipeline's capacity is one of the most important parameters in any design specification. Hence, the most difficult challenge in the connectivity solution is how to deal with all these issues important to maintaining the fluid flow from inlet to outlet. This work is sometimes called flow assurance, which will help to find out technological options in order to establish appropriate control measures; planning of pipelines cleaning; as well as pipelines maintenance. For our work, we will study the multiphase flow assurance of an oil-gas mixture in subsea pipeline of $25 \mathrm{~km}$ length from CNV oilfield to CPP3 at Bach Ho oilfield. 


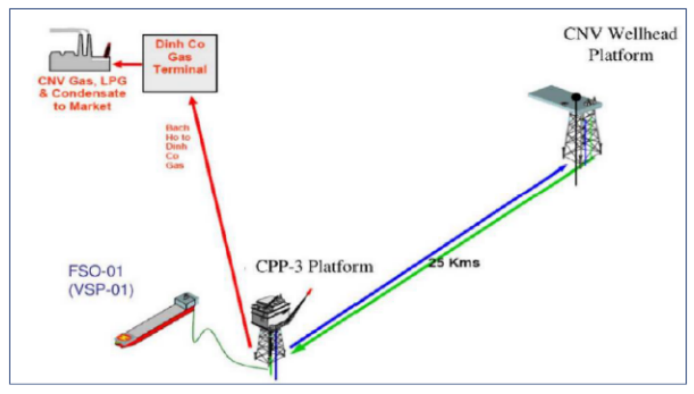

Figure 1. Scheme of the pipeline from Ca Ngu Vang Wellhead Platform to Central Processing Platform 3 of Bach Ho oilfield [1].

Flow assurance - making sure the fluid flows as intended - relies heavily on mathematical models and the simulations they enable. Simulating the flow and everything affecting it contributes to problem prevention and efficiency, from feasibility studies through detailed engineering to operation. Results coming out of such simulations need to be verified as reliably as possible.

In our study, two simulations were built and run using field data. For the first one, a slug tracking module was built and helped to determine the frequency and length of the slugs, as well as the surge volume which can help to design the slug catcher at the outlet of the pipeline. The slug catcher is used for avoiding the flood occurring at the outlet due to accumulation of the slugs. For the second one, a thermal hydraulic simulation was built and helped to forecast changes in pressure and temperature which can help to choose the suitable PPD chemicals that prevent the formation of wax in the pipeline. We also varied the flow rates to see how they affect the results. This study has therefore a high practical aspect and hence can be directly applied in the field. Although the choice of PPD for CNV crude oil was already studied in the work of Do [1], this author did not study the slug tracking behavior in the pipeline. Slug tracking is therefore the most important contribution of our study about flow assurance in the pipeline connecting CNV oilfield to CPP3.

\section{THEORETICAL BACKGROUND}

\subsection{Slug initiation mechanism}

Slugs initiate along pipelines under three slugging mechanisms, namely hydrodynamic slugging, terrain slugging and severe slugging, depending on the pipeline geometrical configuration. In this study, we investigate the slug frequency in a pipeline that is generated under hydrodynamic and terrain slugging only.

Slugs forming in horizontal pipes are called hydrodynamic slugs, and tend to be relatively short, typically less than 500 pipe diameters [2]. Hydrodynamic slugging is described as the slugging mechanism caused by a flow disturbance to the gasliquid interface in a stratified flow close to the pipeline entrance region. The pressure reduction un the stratified gas channel due to the gas acceleration results in a suction force acting on the liquid phase which overcomes the gravity and surface tension forces acting on the liquid layer. This force is called Bernoulli effect. This mechanism is the Kelvin-Helmholtz stability criterion for transition to slug flow [3]. As a result, a new wave is generated which grows to form a slug. Hydrodynamically, Taitel and Dukler [3] related the slug frequency to the time it takes for a slug to be initiated at the pipe entrance region. Figure 2 depicts the slug initiation process, as a small wave forms on the interface and grows to block the pipe cross section, forming a slug. Behind the formed slug, the liquid level drops because of liquid being swept into the slug body. The time required for the dropped liquid level to rebuild for a new slug to be triggered is the inverse of slug frequency.

Terrain slugging is caused by the hilly-terrain configuration of a pipeline, where liquid accumulates and blocks the lower dip, resulting in an initiated slug. The mechanism of terrain slugging is governed by a flooding phenomenon and is promoted by the upward inclination angle (Figure 3). Liquid has a tendency to flow towards the low point and block the gas. The gas pressure builds until the gas reaches the low point and begins to escape into the liquid-filled uphill section. Once that occurs, the liquid column carried by the gas gets shorter and shorter, and it becomes easier for the pressure to push it further upwards. As a result, both the liquid and the gas accelerate out of the pipe.

Neither the downhill nor the uphill parts need to be as steep as illustrated here, a degree of elevation can be sufficient for this to happen. It can occur at any low point in the pipe, it does not have to be near the outlet. Risers may create these sorts of slugs if the seabed in front of the riser slopes downwards. Terrain generated slugs can have periods of several hours.

\section{Trang 104}




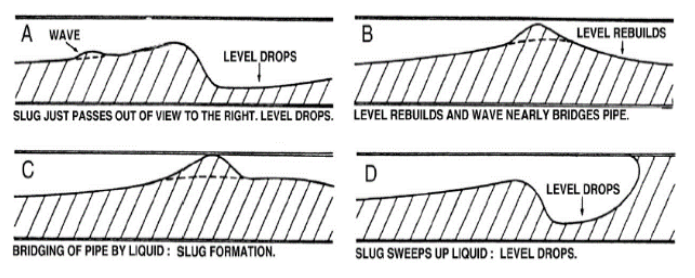

Figure 2. The process of hydrodynamic slug formation [3].

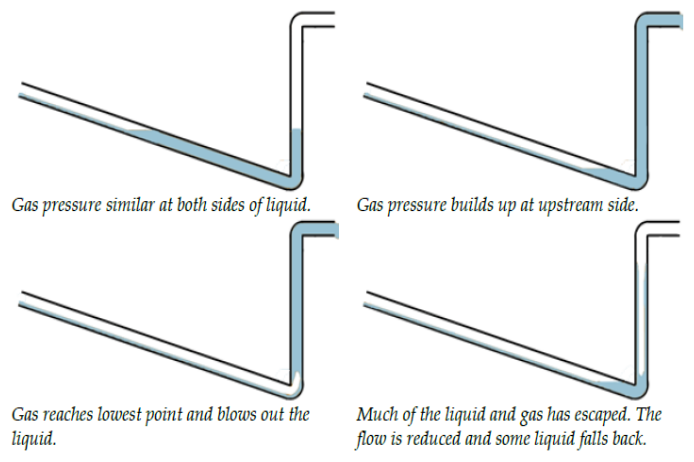

Figure 3. The process of terrain slug formation [2].

Slugs are generally unwanted because they can create significant pressure fluctuations, and they can also lead to gas and liquid arriving at the processing facilities unevenly, causing tanks to flood. Since gases have lower density and therefore lower heat capacity than liquids, gases cool faster, so the temperature reduction during periods of high gas content can more easily cause hydrates to form. The increased intermittent liquid velocity can also accelerate corrosion. In brief, not only slug leads to flooding at the receive end but it also creates pressure transients and increase deposits and corrosion.

\subsection{Conservation equations}

For two-phase flow in pipes, most of the analysis and simulations is based on solving the equations of conservation of mass, momentum and energy for each phase. We detail these equations in the following.

\subsubsection{Continuity equation}

For the gas phase:

$\frac{\partial}{\partial t}\left(\alpha_{G} \rho_{G}\right)=-\frac{1}{A} \frac{\partial}{\partial x}\left(A \alpha_{G} \rho_{G} v_{G}\right)+\psi_{G}+G_{G}(1)$

For the liquid phase at the wall:

$\frac{\partial}{\partial \mathrm{t}}\left(\alpha_{\mathrm{L}} \rho_{\mathrm{L}}\right)=-\frac{1}{\mathrm{~A}} \frac{\partial}{\partial \mathrm{x}}\left(\mathrm{A} \alpha_{\mathrm{L}} \rho_{\mathrm{L}} \mathrm{v}_{\mathrm{L}}\right)-\psi_{\mathrm{G}} \frac{\alpha_{\mathrm{L}}}{\alpha_{\mathrm{L}}+\alpha_{\mathrm{D}}}$

$-\psi_{\mathrm{e}}+\psi_{\mathrm{d}}+\mathrm{G}_{\mathrm{L}}(2)$

For liquid droplets:

$$
\begin{aligned}
& \frac{\partial}{\partial t}\left(\alpha_{D} \rho_{L}\right)=-\frac{1}{A} \frac{\partial}{\partial x}\left(A \alpha_{D} \rho_{D} v_{D}\right)-\psi_{G} \frac{\alpha_{D}}{\alpha_{L}+\alpha_{D}} \\
& -\psi_{e}+\psi_{d}+G_{D}(3)
\end{aligned}
$$

Subscripts G, L, I and D indicate gas, liquid, interface and droplets, respectively

$\alpha_{\mathrm{G}}, \alpha_{\mathrm{L}}, \alpha_{\mathrm{D}}$ : gas, liquid film and liquid droplets volume fractions

$\mathrm{v}_{\mathrm{G}}, \mathrm{v}_{\mathrm{L}}, \mathrm{v}_{\mathrm{D}}$ : velocity $(\mathrm{m} / \mathrm{s})$

A : pipe cross-sectional area

$\psi_{\mathrm{G}}$ : mass-transfer rate between the phases

$\psi_{\mathrm{e}}, \psi_{\mathrm{d}}:$ the entrainment and deposition rate

$\mathrm{G}_{\mathrm{f}}$ : possible mass source of phase $\mathrm{f}$

\subsubsection{Momentum equation}

For the gas phase and liquid droplets:

$$
\begin{aligned}
& \frac{\partial}{\partial \mathrm{t}}\left(\alpha_{\mathrm{G}} \rho_{\mathrm{G}} \mathrm{v}_{\mathrm{G}}+\alpha_{\mathrm{D}} \rho_{\mathrm{L}} \mathrm{v}_{\mathrm{D}}\right)=-\left(\mathrm{v}_{\mathrm{G}}+\mathrm{v}_{\mathrm{D}}\right)\left(\frac{\partial \mathrm{p}}{\partial \mathrm{x}}\right) \\
& -\frac{1}{\mathrm{~A}} \frac{\partial}{\partial \mathrm{x}}\left(\mathrm{A} \alpha_{\mathrm{G}} \rho_{\mathrm{G}} \mathrm{v}_{\mathrm{G}}^{2}+A \alpha_{\mathrm{D}} \rho_{\mathrm{L}} \mathrm{v}_{\mathrm{D}}^{2}\right) \\
& -\lambda_{\mathrm{G}} \frac{1}{2} \rho_{\mathrm{G}}\left|\mathrm{v}_{\mathrm{G}}\right| \mathrm{v}_{\mathrm{G}} \frac{\mathrm{S}_{\mathrm{G}}}{4 \mathrm{~A}}-\lambda_{\mathrm{i}} \frac{1}{2} \rho_{\mathrm{G}}\left|\mathrm{v}_{\mathrm{r}}\right| \mathrm{v}_{\mathrm{r}} \frac{\mathrm{S}_{\mathrm{i}}}{4 \mathrm{~A}} \\
& +\left(\mathrm{v}_{\mathrm{G}} \rho_{\mathrm{G}}+\mathrm{v}_{\mathrm{D}} \rho_{\mathrm{L}}\right) \mathrm{g} \cos \alpha+\psi_{\mathrm{G}} \frac{\mathrm{v}_{\mathrm{L}}}{\mathrm{v}_{\mathrm{L}}+\mathrm{v}_{\mathrm{D}}} \mathrm{v}_{\mathrm{a}} \\
& +\psi_{\mathrm{e}} \mathrm{v}_{\mathrm{i}}-\psi_{\mathrm{D}} \mathrm{v}_{\mathrm{D}}(4)
\end{aligned}
$$


For the liquid phase at the wall:

$\frac{\partial}{\partial t}\left(\alpha_{L} \rho_{L} v_{L}\right)=-v_{L}\left(\frac{\partial p}{\partial x}\right)-\frac{1}{A} \frac{\partial}{\partial x}\left(A \alpha_{L} \rho_{L} v_{L}^{2}\right)$

$-\lambda_{\mathrm{L}} \frac{1}{2} \rho_{\mathrm{L}}\left|\mathrm{v}_{\mathrm{L}}\right| \mathrm{v}_{\mathrm{L}} \frac{\mathrm{S}_{\mathrm{L}}}{4 \mathrm{~A}}+\lambda_{\mathrm{i}} \frac{1}{2} \rho_{\mathrm{G}}\left|\mathrm{v}_{\mathrm{r}}\right| \mathrm{v}_{\mathrm{r}} \frac{\mathrm{S}_{\mathrm{i}}}{4 \mathrm{~A}}$

$+\mathrm{v}_{\mathrm{L}} \rho_{\mathrm{L}} \mathrm{g} \cos \alpha-\psi_{\mathrm{G}} \frac{\mathrm{v}_{\mathrm{L}}}{\mathrm{v}_{\mathrm{L}}+\mathrm{v}_{\mathrm{D}}} \mathrm{v}_{\mathrm{a}}-\psi_{\mathrm{e}} \mathrm{v}_{\mathrm{i}}+\psi_{\mathrm{D}} \mathrm{v}_{\mathrm{D}}$

$-\mathrm{v}_{\mathrm{L}} \mathrm{d}\left(\rho_{\mathrm{L}}-\rho_{\mathrm{G}}\right) \mathrm{g} \frac{\partial \mathrm{v}_{\mathrm{L}}}{\partial \mathrm{x}} \sin \alpha(5)$

$\alpha$ : pipe inclination with the vertical

$\mathrm{S}_{\mathrm{G}}, \mathrm{S}_{\mathrm{L}}$ and $\mathrm{S}_{\mathrm{i}}$ : wetted perimeters of the gas, liquid and interface

\subsubsection{Energy conservation equation}

$$
\begin{aligned}
& \frac{\partial}{\partial t}\left[\begin{array}{l}
\mathrm{m}_{\mathrm{G}}\left(\mathrm{E}_{\mathrm{G}}+\frac{1}{2} \mathrm{v}_{\mathrm{G}}^{2}+\mathrm{gh}\right)+\mathrm{m}_{\mathrm{L}}\left(\mathrm{E}_{\mathrm{L}}+\frac{1}{2} \mathrm{v}_{\mathrm{L}}^{2}+\mathrm{gh}\right) \\
+\mathrm{m}_{\mathrm{D}}\left(\mathrm{E}_{\mathrm{D}}+\frac{1}{2} \mathrm{v}_{\mathrm{D}}^{2}+\mathrm{gh}\right)
\end{array}\right]= \\
& \frac{\partial}{\partial \mathrm{x}}\left[\begin{array}{l}
\mathrm{m}_{\mathrm{G}} \mathrm{v}_{\mathrm{G}}\left(\mathrm{H}_{\mathrm{G}}+\frac{1}{2} \mathrm{v}_{\mathrm{G}}^{2}+\mathrm{gh}\right)+\mathrm{m}_{\mathrm{L}} \mathrm{v}_{\mathrm{L}}\left(\mathrm{H}_{\mathrm{L}}+\frac{1}{2} \mathrm{v}_{\mathrm{L}}^{2}+\mathrm{gh}\right) \\
+\mathrm{m}_{\mathrm{D}} \mathrm{v}_{\mathrm{D}}\left(\mathrm{H}_{\mathrm{D}}+\frac{1}{2} \mathrm{v}_{\mathrm{D}}^{2}+\mathrm{gh}\right)
\end{array}\right] \\
& +\mathrm{H}_{\mathrm{s}}+\mathrm{U}(6)
\end{aligned}
$$

$\mathrm{E}$ : internal energy per unit mass

$\mathrm{h}$ : elevation

$\mathrm{H}_{\mathrm{s}}$ : enthalpy from mass source

$\mathrm{U}$ : heat transfer from pipe walls

\subsubsection{Other equations}

The simulations also uses other equations that we do not detail here but the lecturer is invited to read the paper of Kjell H. Bendlksen et al. [4] for further details about the pressure equation and the interfacial mass transfer equations. The pressure equation may be solved simultaneously with the conservation equations for the pressure and phase velocities and thus allow a stepwise time integration. The applied interface mass-transfer model can treat both normal condensation or evaporation and retrograde condensation in which a heavy phase condenses from the gas phase as the pressure drops.

\subsection{Slug frequency predictive model}

A slug frequency predictive model, empirical or mechanistic, is an essential part of any slug flow model.
Some authors suggested that the slug frequency can be correlated to a Froude number based on different parameters such as superficial liquid velocity, or the time taken for a slug to be initiated at the pipe entrance region, or the pipe's geometry, etc... Several correlations have been developed to predict slug frequency, ranging from simple correlations such as Gregory and Scott [5] and Heywood and Richardson [6] to more complicated ones that take into account the pipe length and mechanistic variables, such as the Shea et al. [7] and Hill and Wood [8] correlations. We present below the correlation of Shea et al. [7] as an example. These authors developed a slug frequency correlation as a function of pipe length (measured from the pipeline inlet), which is not included in any other published slug frequency correlation:

$$
\mathrm{F}_{\mathrm{s}}=\frac{0.47 \mathrm{v}_{\mathrm{SL}}^{0.75}}{\mathrm{~d}^{1.2} \mathrm{~L}_{\mathrm{p}}^{0.55}}(7)
$$

$\mathrm{F}_{\mathrm{s}}$ is the Froude number; vSL is the velocity of the superficial liquid; $d$ and $L_{p}$ are respectively the diameter and length of the pipe.

Although this correlation has no theoretical basis and is a pure curve fitting, their validation study with large laboratory and field data shows a fair agreement, with $76 \%$ of the predictions lying within a factor of 2 of the data, and $95 \%$ of the predictions within a factor of 3 of the data. The Shea et al. [7] correlation was originally developed and used for slug tracking to tune the delay constant (minimum time duration between two generated slugs).

\section{PIPELINE GEOMETRY AND FLUID PROPERTIES}

The geometrical properties of the pipeline, as well as the properties of the crude oil extracted from CNV oilfield are respectively presented in Table $\mathbf{1}$ and Table 2. These properties were served as entry data for the simulations. It is important to have a detailed mapping of elevations of the pipeline on the seabed, which is very critical for a slug tracking research. However, this is not a simple task to archive in reality, especially for such a long pipe $(25 \mathrm{~km})$. Hence, simplifications in modeling of pipeline's geometry are unavoidable. In this study, we used the pipeline's geometry provided in the work of Do [1].

\section{Trang 106}


Table 1. Geometrical and technical characteristics of the pipeline.

\begin{tabular}{|l|l|}
\hline \multicolumn{1}{|c|}{ Description } & Specification \\
\hline Outer diameter $(\mathrm{mm})$ & 273.1 \\
\hline Wall thickness $(\mathrm{mm})$ & 20.1 \\
\hline Inner diameter $(\mathrm{mm})$ & 232.9 \\
\hline Riser's height at the inlet $(\mathrm{CNV}$ WHP) $(\mathrm{m})$ & 55 \\
\hline Riser's height at the outlet $(\mathrm{CPP} 3)(\mathrm{m})$ & 46.5 \\
\hline Insulation layer & $41.9 \mathrm{~mm}$ PU \\
\hline Ambient temperature $\left({ }^{\circ} \mathrm{C}\right)$ & 24 \\
\hline Convective heat transfer mean coefficient $\left(\mathrm{W} / \mathrm{m}^{2} \cdot \mathrm{C}\right)$ & 1.913 \\
\hline Concrete coating & $53.5 \mathrm{~mm}$ \\
\hline Thermal conductivity of concrete coating $(\mathrm{W} / \mathrm{mK})$ & 2.0 \\
\hline Pipelines steel & API $5 \mathrm{~L} \mathrm{X65}$ \\
\hline Thermal conductivity of pipelines steel $(\mathrm{W} / \mathrm{mK})$ & 45.0 \\
\hline
\end{tabular}

Table 2. Properties of the crude oil extracted from CNV oilfield.

\begin{tabular}{|l|l|}
\hline \multicolumn{1}{|c|}{ Description } & Specification \\
\hline API at $60^{\circ} \mathrm{F}$ & $43.3-44.6$ \\
\hline Density at $15^{\circ} \mathrm{C}$ & $0.8071 \mathrm{~g} / \mathrm{mL}$ \\
\hline Dynamic viscosity at $60^{\circ} \mathrm{C}$ & $2.322 \mathrm{cst}$ \\
\hline Pour point & $30^{\circ} \mathrm{C}$ \\
\hline Wax Appearance Temperature (WAT) & $64^{\circ} \mathrm{C}$ \\
\hline Gas Oil Ratio & $2694 \mathrm{scf} / \mathrm{bbl}$ \\
\hline Water content & $0.32 \%$ \\
\hline Asphaltene content & $<0.05 \%$ \\
\hline Paraffin content & $18.10 \%$ \\
\hline
\end{tabular}

\section{RESULTS AND DISCUSSIONS}

The simulated results of slug tracking after 24 hours are presented in Figures 4, 5 and $\mathbf{6}$. We can draw some following observations:

a) For all the flow rates varying from 2000 to $7000 \mathrm{bbl} /$ day, we observe clearly the formation of slugs at the outlet of the pipeline (Figure 4).

b) The maximum surge volume increases when the flow rate at inlet decreases (Figure 5). From the results, we deduce that the volume of the slug catcher at the outlet must be at least $100 \mathrm{~m}^{3}(630 \mathrm{bbl})$ in order to avoid flooding.

c) When the flow rate at the inlet decreases, the number of slugs decreases, as well as the frequency

(Figure 6). However, as we already mentioned at point b: the surge volume increases when the flow rates decreases. For this reason, working at high rate of flow may be better for the equipment (to avoid large surge volume which can induce high hydraulic hammer). The simulated results of the thermal hydraulic simulation to predict the evolution of temperature and pressure in the pipeline are presented in Table 3. We note that the temperature of the liquid in the pipeline is lower than the WAT. This requires the use of PPD in order to lower the WAT to avoid formation of wax which can reduce significantly the transport capacity of the pipeline. According to Do [1], the most suitable PPD for CNV crude oil is EC6509A. This PPD can decrease the pour point of $\mathrm{CNV}$ crude oil from 33 to $18^{\circ} \mathrm{C}$, which is well below the temperature at the outlet of the pipeline.
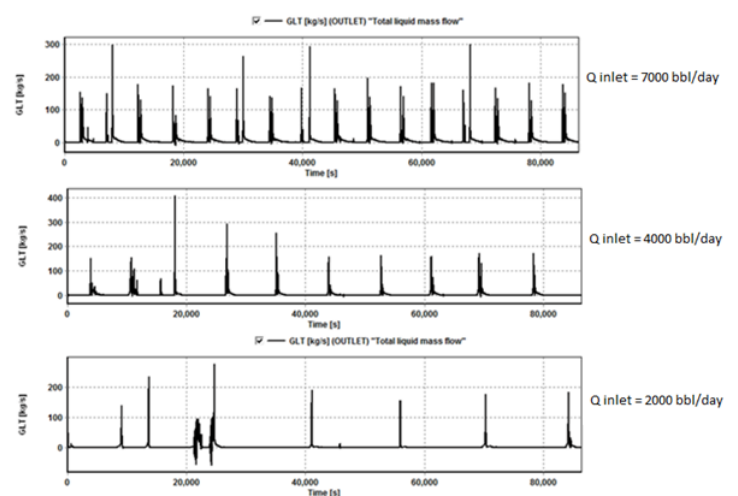

Figure 4. Total liquid mass flow rate at the outlet of the pipeline. 


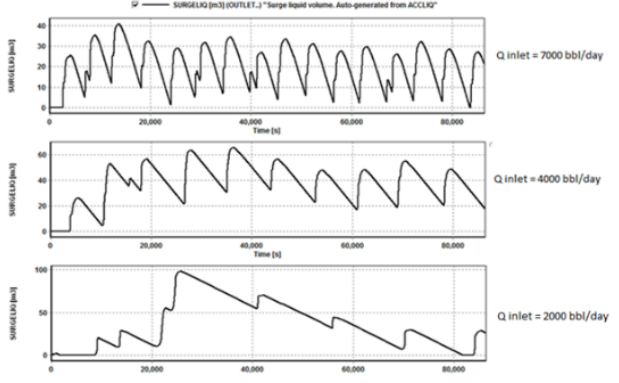

Figure 5. Surge liquid volume at the outlet of the pipeline.
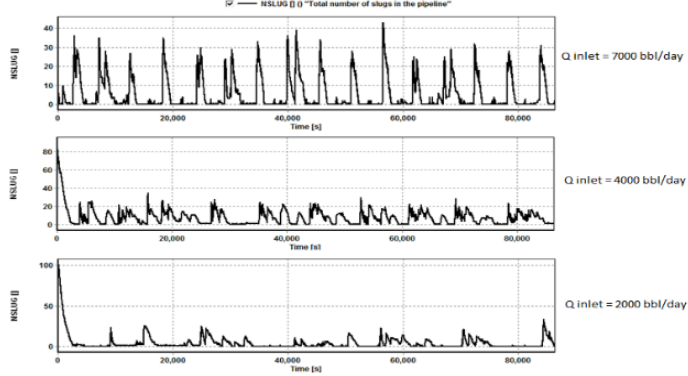

Figure 6. Total number of slugs in the pipeline.

Table 3. Summary of results of thermal hydraulic simulation in the pipeline.

\begin{tabular}{|l|r|r|r|}
\hline$Q_{\mathrm{CNV}}(\mathrm{bbl} / \mathrm{d})$ & 7000 & 4000 & 2000 \\
\hline $\mathrm{P}_{\mathrm{CNV}}$ (bar) & 49.3 & 44.3 & 19.3 \\
\hline $\mathrm{P}_{\mathrm{CPP} 3}(\mathrm{~b} a r)$ & 40 & 40 & 17 \\
\hline $\mathrm{T}_{\mathrm{CNV}}\left({ }^{\circ} \mathrm{C}\right)$ & 64 & 42 & 30 \\
\hline $\mathrm{T}_{\mathrm{CPP} 3}\left({ }^{\circ} \mathrm{C}\right)$ & 39 & 26 & 24 \\
\hline
\end{tabular}

\section{CONCLUSIONS}

This study has shown that the formation of slugs in such a long pipe with different points of elevation is unavoidable, no matter what the flow rate at the inlet is. The only way to reduce the impact of slugs to the equipment at the outlet is to design a slug catcher capable to capture the maximum surge volume which is about $630 \mathrm{bbl}$. The study also showed the necessity of using a PPD chemical (EC6509A in this case) in order to lower the WAT of the liquid, if not, the paraffin would be formed in the pipeline during operation and this can perturb significantly the transport capacity of the system

\section{Bảo đảm dòng chảy trong đường ống dẫn dầu từ mỏ Cá Ngừ Vàng tới giàn xử lý trung tâm số 3 mỏ Bạch Hổ}

- Phạm Sơn Tùng

Trường Đại học Bách Khoa, ĐHQG-HCM

- Mai Cao Lân

Trường Đại học Bách Khoa, ĐHQG-HCM

Đại học Qeenland, Úc

\section{TÓM TÁ́T}

Bài viết này có mục đích tìm ra giải pháp tối ưu trong việc đảm bảo dòng chảy của hỗn hợp dầu và khí trong các đường ống dẫn dầu dưới biển nói chung và cho $25 \mathrm{~km}$ đường ống tù̀ mỏ Cá Ngừ Vàng tới dàn xử lý trung tâm số 3 của mỏ Bạch Hổ

nói riêng. Từ các phương trình bảo toàn khối lượng, động lượng và năng lượng, cùng với cơ sở lý thuyết của chế độ dòng chảy đa pha, tính chất chất lưu, cũng như các tính chất hình học và nhiệt học của đường ống, hai mô hình hóa với các lưu

\section{Trang 108}


lượng dòng chảy khác nhau đã được xây dựng: 1) Mô hình thứ nhất có mục đích theo dõi sự hình thành dòng chảy dạng nút lỏng để dự đoán các chỉ số như tần xuất xuất hiện, chiều dài nút lỏng và thể tích tràn. Kết quả mô phỏng có ý nghĩa thực tế cao trong việc tìm ra thể tích tối ưu cho khả năng tiếp nhận của thiết bị chia tách dầu-khí tại đầu ra

Từ khóa: Bảo đảm dòng chảy, Mô hình hóa dòng chảy đa pha, Dòng chảy dạng nút lỏng, Thiết bị bắt nút lỏng.

\section{TÀI LIẸU THAM KHẢO}

[1]. Do Xuan Hoa, 2008, Tối ưu hóa quá trình vận chuyển dầu khí đa pha trong đường ống ngầm dưới biển từ mỏ Cá Ngừ Vàng đến giàn xử lý trung tâm số 3, Graduate thesis, Faculty of Geology and Petroleum Engineering, Ho Chi Minh City University of Technology.

[2]. Ove Bratland, 2010, Pipe flow 2: Multiphase flow assurance, 373 pages.

[3]. Taitel, Y., Dukler, A., 1976, A model for predictive flow regime transitions in horizontal and near horizontal gas-liquid flow, AIChE J., 22 (1), pp. 47-55.

[4]. Kjell H. Bendlksen, Dag Maines, Randl Moe, Sven Nuland, 1991, The dynamic two-fluid model OLGA: Theory and Application, SPE Production Engineering, pp. 171-180. (slug catcher/separator); 2) Mô hình thứ hai nghiên cứu về các quá trình nhiệt thủy động lực trong đường ống nhằm dụ̣ đoán sự thay đổi của nhiệt độ và áp suất, từ đó có giải pháp thích hợp trong thực tế khi lựa chọn hóa chất làm giảm nhiệt độ đông đặc của dầu.

[5]. Gregory, G., Scott, D., 1969, Correlation of liquid slug velocity and frequency in horizontal cocurrent gas-liquid slug flow, AIChE J., 15 (6), pp. 933-935.

[6]. Heywood, N., Richardson, J., 1979, Slug flow of air-water mixtures in a horizontal pipe: determination of liquid holdup by gamma-ray absorption, J. Chem. Eng. Sci. 34, pp. 17-30.

[7]. Shea, R., Eidsmoen, H., Nordsveen, M., Rasmussen, J., Xu, Z., Nossen, J., 2004, Slug frequency prediction method comparison, BHRG Multiphase Production Technology Proceedings, Banff, Canada.

[8]. Hill, T., Wood, D., 1994, Slug flow: occurrence, consequences, and prediction, SPE 27960, Presented at University of Tulsa Centennial Petroleum Engineering Symposium, Tulsa, Oklahoma. 